\title{
Impact of Conflict Induced Displacement on Primary and Secondary Schooling in Pakistan: An Empirical Analysis
}

\author{
Anayat Ullah ${ }^{1)}$, Syed Hasnain Ali Abbas ${ }^{2)}$, Faryal Shah ${ }^{3)}$, Muneer Khan Orakzai ${ }^{4)}$ \\ ${ }^{1)}$ National University of Medical Sciences (NUMS), Rawalpindi, Pakistan \\ 2) Regional Urban Humanitarian \& Public Health Coordinator-Asia at Oxfam International \\ 3) Virtual University of Pakistan, Islamabad, Pakistan \\ 4) Department of Management Sciences, Abasyn University, Peshawar \\ Email:au.shinwari@gmail.com ${ }^{l)}$
}

\begin{abstract}
The impact of armed conflict on primary and secondary schooling is very hazardous and apparent. Since, 2001 the conflict has made millions of people displaced in the form of Internally Displaced Persons (IDPs) mainly from Tribal Areas on western border with Afghanistan to the settled areas within Pakistan. This research addressed the impact of internal conflict on primary and secondary level school children during displacement at Jalozai camp, Khyber Pukhtunkhwa. For that reason, the household survey was conducted at Jalozai IDPs camp. The survey results indicate that conflict induced displacement has negatively impacted the level of schooling both at primary and secondary level. However, the impact is more hazardous for secondary schooling. Due to some socio-economic and cultural constraints, mostly female students were dropout of schools at secondary kevel. In addition, conflict affected the socio-economic status of the marginalized displaced people which either way affected the schooling of displaced children.
\end{abstract}

Keywords: conflict, displacement, schooling, socio-economic status, Pakistan

\section{Introduction}

It has been mainly observed that armed conflict has led to negative impact on education sector (Marchais, G. et al., 2021). This is primarily seen in the context of primary \& secondary level schooling of impact region. The objective revolves around in understanding the nexus between armed conflict and schooling exploring avenues for reducing the impact through policy measures directed at education sustainability. This is evident on research conducted in this area with role of conflict towards education and socio economic wellbeing (Mueller, H., \& Techasunthornwat, C, 2020; Justino, P. 2010; Collier, 2007). Particularly, in case of conflict hit countries, the average years spend in schools is reduced as compared to the rest of the countries (Fergusson, L et al., 2020; Akresh and De Walque, 2008). This is also understood by different barriers being created towards education attainment in pre and post conflict situation with indirect impact felt through livelihood, household income, child labor, lack of services \& depleted social infrastructure on level of children education attainment (Avendaño-Vásquez, C. et al. 2021; Dryden-Peterson, 2010).

In the education sector, it is estimated that due to conflict, half of global primary aged population drops out of school with internal impact felt more heavily through loss of income, livelihood, property and hard \& soft infrastructure (UNESCO, 2013). It has been observed through evidence based research work that, even after donor support which is mainly directed at upgrading the social infrastructure fulfilling the needs at primary level, with less support 
offered to secondary and tertiary education despite the fact that conflict impact is heavily felt at secondary level (Lyttleton-Smith, J., 2019; UNHRC, 2009; Shields and Paulson, 2014). The above channel is seen from the lens of mobilization of IDP's in the form of loss of capital, decrease in schooling \& income level, displacement of population and loss of infrastructure. This is most common associated with displacement affecting the children schooling at both primary and secondary level (Al Munifi, A. et al. 2021).

The current research study evaluates the barriers, problems and linkage of conflict and education in the context of impact on schooling and other relevant social economic indicators. This is mainly associated with IDP's gathered from Federally Administered Tribal Area (ExFATA) areas of District Khyber (81\%), Bajaur (12\%) and Mohmand (7\%) in Jalozai camp which have direct and indirect link with level of children schooling both at primary and secondary level. The research work also sheds light on understanding the barriers and challenges faced by IDP's and provide policy recommendations for stabilizing the lives of internally displaced population through intervention by the government and international donor agencies.

Societies will always try to devise mechanism in the time of crisis situation and in this context conflict has been a major cause experienced around the world. In order to gauze the limitations and applicability of conflict impact on schooling will help towards reforming the society and needed intervention required in the medium to long run. The armed conflict impact is usually felt through displacement of population which is visible at both micro and macro level (Rice et al., 2006). The less developed countries in conflict prone state require international assistance and development funds for sustaining the children schooling not possibly link with the virtual needs and to accomplish the Education for All (EFA) goals (Brannelly et al., 2009). During conflict, education receives little focus and results in children dropouts from schooling (Boyden and Ryder, 1996; Crisp, 2010).

The communities involved in conflict, one of the most important concerns is with loss of property, income and education of the children both at primary and secondary level (Bendavid, E. et al., 2021). The post conflict there is slow recovery rate of education level, income and livelihood patterns in case of IDP's (Ozaltin, D. 2021;Crisp, 2010). It is also understood that the average recovery rate for primary school enrolment is larger as compared to secondary enrolment in post conflict scenario (Enebi, A. et al. 2021; Chen \& Querol, 2007).

\section{Literature Review}

\subsection{Conflict and Schooling: Global Evidence}

Policies are viewed in the context of its pre and post evaluation results understanding different results from evidence based policy research in the area of conflict and education. It is estimated that more than 50 percent of the population leaving homes are associated with children in conflict hit areas, directly impacting the level of education and socio-economic status (UNICEF, 2009). This is usually noted in case of sudden migration, distribution of education among different strata of effected population, loss of infrastructure and employment, resource deprivation, opportunity cost of skilled labour, lower returns in education at primary and secondary level biased attitude towards girl's education (Chamarbagwala, 2008).

In case of Zimbabwe civil war, boys were focused with more investment in secondary 
education with results of female drooping out of schooling (Alderman and Kinsey, 2006). This can be seen also in the context of Rwanda civil war where children have been directly and indirectly affected through drop in income and decreasing returns on education (Akresh \& Walque, 2008). Moreover, evaluating Tajikistan civil war in early 1990's resulted in decrease in girl's education as compared to boys with strong impact on secondary school enrolment as compared to primary level (Swee, 2009; Shemyakina, 2007).

\subsection{Conflict and Schooling: Pakistan Perspective}

Pakistan has encountered a lot of contention since beginning as parcel from British India in 1947, question of Jammu and Kashmir, strife highlighted through Taliban agitators, struggle in Ex-FATA after 9/11 assault, dislodged populace because of activity of Zarb-e-Azab, nearby and territorial clash circumstance including Sectarianism and Nationalist Movement's causing 1200 passing's with removal of one million populaces from Ex-FATA (Chughtai, 2013). It is important to note that the Tribal belt previously entitled as FATA, is now part of Khyber Pukhtoonkhwa (KP) Province in Pakistan upon recommendation of federal government in 2017 (Ali, I., 2018). The region of Ex-FATA consists of 7 Agencies and 6 Frontier Regions and now all were merged in KP province

After 9/11 Pakistan's choice to assume a front job in war against terror in Ex-FATA and thus it has led the country state into a dangerous circumstance. From a decade ago, the Pakistan armed force was occupied with numerous activities against aggressors in various districts of Ex-FATA and the traditionalist aggressor's bunches have wrecked the social textures and monetary structure of the entire society (Chughtai, 2013). An expected 5 million individuals have been uprooted by struggle and human rights infringement in Ex-FATA, since 2004. The neighbourhood individuals of Ex-FATA were experiencing extended nature of dislodging (UNHCR, 2009).

Pakistan has been host to bunch of conflicts in various structures which has straightforwardly and by implication influenced the populace fundamentally at essential and optional dimension of tutoring. There are boundaries seen in the method for teaching used for Ex-FATA understudies both from demand and supply side viewpoint. The demand side components incorporate societal and family inclination towards instruction, sexual orientation and occupation with uncommon thoughtfulness regarding young ladies training confronting versatility issues, early marriage and traditions confinements with young men are pressurized to add to the family unit salary trade-off for tutoring for gaining employment. Also, along these lines tutoring winds up outlandish for them to proceed. The supply side obstructions incorporate help from government and donor agencies in the region of arrangement for foundation of schools, fundamental administrations for wellbeing, supply of water, separate toilets for boys and girls in schools, supply of educators and security (UNICEF, 2013).

Understanding the effect of conflict induced displacement on youngster's education requires uncommon consideration since children will in general experience in terms of the effect of conflict. The present examination attempts to research the effect of contention incited uprooting on IDP's of Ex-FATA stayed outdoors at Jalozai camp through finding of answers to the accompanying inquiries:

\section{Research Method}

In this study the quantitative strategy was used for information accumulation through survey questionnaire to analyse the view of IDP's. The effect is comprehended through pre and post 
correlation in the territory of schooling, income, livelihood, business, and difficulties faced by IDP's.

\subsection{Sample}

A sample of 200 family units was chosen out of 5363 aggregate number of displaced families in Jalozai camp for essential information gathering through deliberate arbitrary testing and were broke down through Microsoft Excel and Statistical Packages for Social Sciences (SPSS) program for recognizing the above explanation issue. Furthermore, inferential statistics were also used and for this purpose multiple regression model were used.

\subsection{Data Collection}

In this study researcher has identified two age groups, one for primary schooling (5-11 age children) and one for secondary schooling (12-16 age children) out of 200 households. In primary schooling age group 369 students and in secondary schooling age group 97 students were enrolled in study sample of 200 households. This study is based on cross sectional data collected from Jalozai IDPs camp. The same dependent and independent variables were used both for primary and secondary schooling. The only reason was to know the different impacts of armed conflict on primary and secondary schooling separately.

\subsection{Regression Model}

There are multiple factors that are responsible for variation in dependent variable (years of schooling). So, in this situation when multiple factors are involved, multiple regression models were preferred over the simple linear regression model. For this purpose, two independent models were estimated, one for the primary enrolments (5-11 age group children) and another for secondary enrolments (12-16 age group children) and same independent variables were used for both primary and secondary enrolments. The dependent variable and independent variable are explained below:

An independent model for primary enrolments estimated as:

$\mathrm{Y}_{1}=\beta_{0}+\beta \mathrm{i}_{1}($ Socio-Economic Variables $)+\beta \mathbf{i}_{2}($ Conflict Related Variables $)+\epsilon_{i}$

An independent model for secondary enrolments estimated as:

$\mathrm{Y}_{2}=\beta_{0}+\beta \mathbf{i}_{1}$ (Socio-Economic Variables) $+\beta \mathbf{i}_{2}($ Conflict Related Variables $)+\epsilon_{i}$

Where,

$\mathrm{Y}_{1}$ is years of schooling for individual in a particular age cohort (5-11 age group).

$\mathrm{Y}_{2}$ is years of schooling for individual in a particular age cohort (12-16 age group).

Here analysis was based on two age groups that is ages 5-11 and ages 12-16, because these age groups corresponds with Pakistan's school system - primary and secondary school.

$\beta_{0}=$ Constant.

$\beta i_{1}$ and $\beta i_{2}$ are vector of parameters associated with socio-economic variables and conflict related variables, respectively.

Socio-economic characteristics include: (vector of variables)

Household head education, level of income, gender perspective (the value of gender is 1 if child is male and 0 for otherwise). 
Conflict related variable includes: (vector of variables)

Educational gap after displacement (For how many months you were absent from the school after displacement). Years of displacement (For how many years you were displaced) and camp study environment (here, this variable is used as a dummy variable that takes a value of 1 if a child is satisfied from camp study environment and 0 for otherwise).

In most of the empirical studies conflict is taken as a dummy and they have assigned the value of 1 for those who were affected due to conflict and 0 for otherwise. However, in this case all the respondents were affected from conflict because they all were displaced due to conflict in Ex-FATA. So, only three variables were taken for conflict which has already been mentioned in conflict related variables.

$\epsilon_{i}=$ Error term.

\section{Findings and Discussions}

In this study six independent variables were used, first the 'gender of the child' (it take value of 1 for boy and 0 for girl) second the 'number of absent year' (for how many years the particular child is absent from school after displacement). Third the 'years of displacement' (for how many years the respondent family is displaced). Fourth the 'study environment' after displacement, here this variable is used as a dummy variable which take value of 1 if the respondent is satisfied from the study environment during the days of displacement and 0 for otherwise. Fifth the 'level of income' and in this variable current level of income is studied to know the after impact of conflict on the schooling of IDPs children. Sixth independent variable is 'household head level of education'.

The result of first equation is based on the analysis of primary age school children and the results were discussed in Table 1, which evaluates the impact of conflict induced displacement on primary schooling of IDPs children of Ex-FATA. In this study 369 total number of primary schooling children (5-11 ages) were observed from a sample of 200 households in study area. The value of R-squared is 0.9343 which is a sign of good fitted model and the value of adjusted R-squared is .9317 . The value of root mean square error (MSE) is also smaller and that is 1.32 .

Table 1. Regression analysis of primary schooling

\begin{tabular}{|l|c|c|c|c|c|c|}
\hline $\begin{array}{l}\text { Number of } \\
\text { observations }\end{array}$ & $F(14,355)$ & Probability $>\mathrm{F}$ & R- squared & Adjusted R- squared & Root MSE \\
\hline \multicolumn{1}{|c|}{369} & 360.56 & 0.0000 & 0.9343 & \multicolumn{2}{|c|}{.9317} & 1.32 \\
\hline $\begin{array}{l}\text { Years of } \\
\text { Schooling }\end{array}$ & Coefficient & Standard Error & $\mathrm{t}$-statistics & $\mathrm{P}>[\mathrm{t}]$ & \multicolumn{2}{|c|}{$\begin{array}{r}95 \% \text { confidence } \\
\text { Interval }\end{array}$} \\
\hline $\begin{array}{l}\text { Child } \\
\text { Gender }\end{array}$ & 0.7718818 & 0.1565273 & 4.93 & 0.000 & .464044 & 1.07971 \\
\hline Absent year & 0.4310764 & 0.1354759 & 3.18 & 0.002 & .164640 & .6975127 \\
\hline
\end{tabular}




\begin{tabular}{|l|r|r|r|r|r|r|}
\hline $\begin{array}{l}\text { Displacement } \\
\text { Year }\end{array}$ & 0.3147421 & 0.0446006 & 7.06 & 0.000 & .227027 & .4024568 \\
\hline $\begin{array}{l}\text { Study after } \\
\text { displacement }\end{array}$ & 0.2978847 & 0.1762789 & 1.69 & 0.092 & $\begin{array}{r}- \\
.048797 \\
6\end{array}$ & .644567 \\
\hline $\begin{array}{l}\text { Family } \\
\text { Income }\end{array}$ & 0.0000692 & 0.3139946 & 0.00 & 1.000 & $\begin{array}{r}.617454 \\
2\end{array}$ & .6175926 \\
\hline Education & 2.63606 & 0.3533298 & 7.46 & 0.000 & 1.94117 & 3.330943 \\
\hline
\end{tabular}

The value of child gender is statistically significant and P-value is 0.000 . In study area (Jalozai IDPs camp, Nowshera, Khyber Pukhtunkhwa Province, Pakistan) there were eight primary schools four were boys and four were girl's schools. So, there were no issue for IDPs child to get enrolled in primary level of schooling and also there were no restriction from home side at primary level for getting enrolled in these camp schools. For the reason that these primary age group children were not able to be engaged in work force, similarly, there were no restrictions of Pardah (veil) for girl's children. So, ultimately there were limited barriers in the way of primary age children in IDPs camp.

The value of absent year is also significant and having $\mathrm{P}$-value 0.002 . This variable explains that when IDPs children were displaced so, for how many years they were out of schools. This study came up with a range of 3 months to 3 years schooling gap after displacement from Ex-FATA. This means that, when local people were displaced from Ex-FATA and among these IDPs there were lots of children and obviously they became out of schools as a result of displacement. Consequently, these displaced children remain out of schools within a range of 3 months to 3 years.

The displacement years $\mathrm{P}$ value is 0.000 which is highly significant. This variable explains that for how many years the respondent family is displaced. The higher the years of displacement the higher will be the impact on the years of schooling. Because those IDPs who join IDP camp in 2009 they have fewer opportunities available as compared to other IDPs who were displaced in 2012 and similarly in 2014. Some of the respondents said that during 2009 there was no schooling setup in Jalozai camp and that is the reason way IDPs children were mostly suffered. All those displaced families who join IDPs camp during 2012 and 2014 they were less suffered as compared to those families who were displaced in 2009. For the reason that, in 2009 there were no proper setup of schooling for these Internally Displaced Children (IDC).

The values of study environment and level of income are not statistically significant. Because at primary level of schooling it does not matter as they are in early stage of schooling so primary students do not feel any differences for their study environment. On the other hand, after displacement there were no costs of schooling for IDC in camps. So, IDC don't feel any economic burden in their way of schooling. The P-value for household head education level is highly significant and almost 0.000. This shows that the higher the level of household head education, the higher will be the years of schooling of a child. So, child gender, absent years, displacement years and household head education is statistically significant and having significant impact on the years of schooling of displaced children. 
The Table 2 explains the impacts of armed conflicts on the schooling of secondary level students after forced displacement from Ex-FATA. In this section 97 total numbers of observations of secondary schooling children (12-16 ages) were observed out of 200 sample households in Jalozai camp. The value of R-squared is 0.9872 and the value of adjusted Rsquared is 0.9852 , which is a sign of good fitted model. The value of root mean square error (MSE) is also smaller and its value is 1.14 .

Table 2. Regression analysis of secondary schooling

\begin{tabular}{|c|c|c|c|c|c|c|}
\hline $\begin{array}{l}\text { Number of } \\
\text { observations }\end{array}$ & $F(13,84)$ & Probability $>F$ & R-squared & \multicolumn{2}{|c|}{$\begin{array}{l}\text { Adjusted } \\
\text { squared }\end{array}$} & $\begin{array}{l}\text { Root } \\
\text { MSE }\end{array}$ \\
\hline 97 & 497.75 & 0.0000 & 0.9872 & \multicolumn{2}{|c|}{.9852} & 1.1419 \\
\hline $\begin{array}{ll}\text { Years } & \text { of } \\
\text { Schooling } & \end{array}$ & Coefficient & Standard Error & t-statistics & $\mathrm{P}>[\mathrm{t}]$ & \multicolumn{2}{|c|}{$\begin{array}{l}95 \% \text { confidence } \\
\text { Interval }\end{array}$} \\
\hline $\begin{array}{l}\text { Child } \\
\text { Gender }\end{array}$ & 0.209024 & 0.4767644 & 0.44 & 0.662 & -.739073 & 1.15712 \\
\hline Absent year & -0.698805 & 0.2223486 & -3.14 & 0.002 & -1.14097 & -.256640 \\
\hline $\begin{array}{l}\text { Displacement } \\
\text { Year }\end{array}$ & 0.0223287 & 0.0733815 & 0.30 & 0.762 & -.123598 & .168256 \\
\hline $\begin{array}{l}\text { Study after } \\
\text { displacement }\end{array}$ & -0.7223707 & 0.272499 & -2.65 & 0.010 & 1.264265 & -.180476 \\
\hline $\begin{array}{l}\text { Family } \\
\text { Income }\end{array}$ & 10.38497 & 0.8434929 & 12.31 & 0.000 & 8.707596 & 12.06235 \\
\hline $\begin{array}{l}\text { Level of } \\
\text { Education }\end{array}$ & -0.276622 & 0.6500823 & -0.43 & 0.672 & $1.569382^{-}$ & 1.016138 \\
\hline
\end{tabular}

The value of child gender is not statistically significant and its value is just 0.44 and its Pvalue is 0.66 which is above the level of 0.05 . While the value of absent year is significant at -3.14 and P-value is less than 0.05 that is 0.002 . So, there is negative relationship between dependent and independent variable. The value of displacement years is not statistically significant and its value is just 0.30 and its $\mathrm{P}$-value is 0.76 which is above the level of 0.05 .

The value of study environment after displacement is -2.65 and its P-value is 0.010 , which is statistically significant. This outcome of this variable is totally based on local people perception about the camp study environment at Jalozai camp. So, after conflicts how study environment is affected during the days of displacement from Ex-FATA. So the result shows that study environment is negatively affected after displacement.

At secondary level of schooling, income shows the higher impact on the dependent variable. The value of t-statistics for level of income is highly significant and almost its value is 12 . This shows that the higher the level of family income, the higher will be the years of schooling of a child. Consequently, at secondary level of schooling income shows the higher 
impact on the years of schooling.

\section{Conclusion}

The paper provides ample of evidence available through literature and empirical results drawn from results showing the negative impact of conflict on schooling outcomes. The results for Pakistan in terms of insecurity and violent conflicts represents one of the key impediments in addition to others for attaining the goals of universal primary and secondary education through intervention and realization of goals through Sustainable Development Goals SDG's. Although, IDP's were exposed to many risks and deprivations for sustaining livelihood, income and more importantly education outcomes, the paper concludes displaced population even after support from Government and Donor agencies faced problems for maintaining old life patterns and for sustainable educational opportunities.

The study also concludes that common issues coupled with mistrust have hampered the efforts diverted towards integration of community and towards facilitation. The results indicate to final conclusion that education can have significant impact on human capital formation and intergenerational outcome for school achievement, income earning opportunities and detrimental effect on secondary education attainment. Furthermore, the increasing number of challenges as witnessed from both demand and supply side including schooling, livelihood, lowering of income and disparities, quality of schooling services and other factors which has impacted the lives of the IDP's who were significantly impacted by conflict in their respective areas.

\section{Recommendations}

Considering the results illustrated above following policy recommendations are noteworthy: Firstly, it is important to mentioned that mostly IDPs were returned to their hometowns after negotiation and peace process. Therefore, it is crucial to ensure and increase the developmental budget for conflict hit areas, in order to fully operationalized the schooling infrastructure. Secondly, special measures should be taken for increasing the level of income of the household which will help in increasing secondary enrolment and decreasing child labour. Most importantly, to increase awareness related to conflict and education through advocacy plan for the long run significance of education in post-conflict era.

\section{References}

Akresh, R. and D. de Walque. 2008. "Armed Conflict and Schooling: Evidence from the 1994 Rwandan Genocide," IZA Discussion Paper No. 3516.

Alderman, H., Hoddinott, J. and Kinsey, B. 2006. "Long Term Consequences of Early Childhood Malnutrition", Oxford Economic Papers, 58 (3): 450-474.

Ali, I. (2018). Mainstreaming Pakistan's federally administered tribal areas. Special Report United States Institute of Peace, url: www. usip. org/sites/default/files/2018-03/sr-421 mainstreaming/pakistan-federally administered-tribal-areas. $p d f$.

AlMunifi, A. A., \& Aleryani, A. Y. (2021). Internal efficiency of Higher education system in armed conflict-affected countries-Yemen case. International Journal of Educational Development, 83, 102394.

Avendaño-Vásquez, C. J., Reina-Gamba, N. C., Daza-Castillo, L. A., \&Quarantini, L. (2021). Nursing interventions in children living under armed conflict situations and quality of life: a scoping review. Journal of Pediatric Nursing, 58, 44-52. 
Ballantine, J. H., \& Spade, J. Z. (2007). Getting started: Understanding education through sociological theory. In Ballantine, J. H., \& Spade, J. Z. (Eds.). Schools and society: A sociological approach to education, third edition. California: SAGE Publications.

Bendavid, E., Boerma, T., Akseer, N., Langer, A., Malembaka, E. B., Okiro, E. A., ... \& Wise, P. (2021). The effects of armed conflict on the health of women and children. The Lancet.

Boyden, J., \& Ryder, P. (1996). Implementing the right to education in areas of armed conflict. University of Oxford, Queen Elizabeth House. Oxford, United Kingdom.

Brannelly, L., Ndaruhutse, S., \& Rigaud, C. (2009). Donors' engagement: supporting education in fragile and conflict-affected states: International Institute for Educational Planning \& CfBT Educational Trust. Paris, France.

Chamarbagwala (2008); 'The Human Capital Consequences of Civil War: Evidence from Guatemala' HiCN Working Paper 59

Chen, Siyan, Loayza, Norman V., and Reynal-Querol, Marta. 2007. "The Aftermath of Civil War.” World Bank Policy Research Working Paper No. 4190.

Chughtai, M. W. (2013). The Impact of Rising Terrorism and Military Operations on Socio Economic Culture of Federally Administered Tribal Areas (FATA) of Pakistan. A Journal of Peace and Development, 3(1), 18-32.

Collier, P. 2007. The Bottom Billion: Why the Poorest Countries Are Failing and What Can Be Done About It. Oxford: Oxford University Press.

Collins, R. (1971). Functional and conflict theories of educational stratification. American Sociological Review, 36(6), $1002 \backslash 1019$.

Crisp, J. (2010). Forced displacement in Africa: Dimensions, difficulties, and policy directions. Refugee Survey Quarterly, 29(3), 1-27.

Dryden-Peterson, S. (2010). Barriers to Accessing Primary Education in Conflict-Affected Fragile States: Literature Review. London: Save the Children

Enebi, A. A., Akong, O. P., \& John, O. O. (2021). The Role of Peace Education in Conflict Resolution in Lagos, NIGERIA. HALLMARK UNIVERSITY, 180.

Fergusson, L., Ibáñez, A. M., \& Riaño, J. F. (2020). Conflict, educational attainment, and structural transformation: La violencia in colombia. Economic Development and Cultural Change, 69(1), 335-371.

Guariso, A., and Verpoorten, M. (2013). Armed Conflict and Schooling in Rawanda: Digging Deeper. LICOS Discussion Papers 343. Leuven: LICOS (Centre for Institutions and Economic Performance), University of Leuven.

Justino, P., 2010. War and Poverty. MICROCON Research Working Paper 32, Brighton: MICROCON

Lai, B. and Thyne, C. (2007) 'The effect of civil war on education 1980-97', Journal of peace research. Vol. 44, No. 3, 2007, pp.277-292.

Lange, M. and Quinn. M. (2003). Conflict, humanitarian assistance and peacebuilding: Meeting the challenges. International Alert London.

Lyttleton-Smith, J. (2019). Objects of conflict:(re) configuring early childhood experiences of gender in the preschool classroom. Gender and Education, 31(6), 655-672.

Marchais, G., Gupta, S., Brandt, C., Justino, P., Leone, M., Lulego, E. K., ... \&Bove, M. (2021). Marginalisation from Education in Conflict-Affected Contexts: Learning from Tanganyika and Ituri in the DR Congo.

Miller, G. (2003). Contemporary Sociology. American Sociological Association, 32(4), 524525.

Mincer, Jacob (1974) 'Schooling, Experience and Earnings', New York: National Bureau of 
Economic Research.

Mooney \& French (2005); 'Barriers And Bridges: Access To Education For Internally Displaced Children. The Brookings Institution-University of Bern, 200523

Mueller, H., \& Techasunthornwat, C. (2020). Conflict and Poverty.

Mustafa, U. (2013). Determinants and implications of major conflicts in Pakistan. Millennial Asia, 4(1), 67-86.

Omoeva, C., Hatch, R. and Moussa, W. (2016). The Effects of Armed Conflict on Educational Attainment and Inequality. [ebook] Washington, D.C., USA: Education Policy and Data Center, p.44.

Ozaltin, D. (2021). Forced migration disentangled: how do armed conflicts lead to displacement? (Doctoral dissertation, University of Kent).

Rice, S., Graff, C., \& Lewis, J. I. (2006). Poverty and civil war: What policymakers need to know. Brookings Global Economy and Development Working Paper.

Ramsbotham, O., Miall, H., \& Woodhouse, T. (2011). Contemporary conflict resolution. Polity.

Shemyakina, O. (2007): “The Effect of Armed Conflict on Accumulation of Schooling: Results from Tajikistan," HiCN Working Paper 12.

Shields, R. and Paulson, J. (2014). 'Development in reverse'? A longitudinal analysis of armed conflict, fragility and school enrolment.' Comparative education.

Swee (2009); 'On War and Schooling Attainment: The Case of Bosnia and Herzegovina' HiCN Working Paper 57

UNESCO (2011). Education for All Global Monitoring Report 2011: The hidden crisis: Armed conflict and education. Paris: UNESCO.

UNESCO, 2013. Children still battling to go to school. Education for All Global Monitoring Report Policy Paper 10.

UNHCR. (2009). Refugees, Asylum-seekers, Returnees, Internally Displaced and Stateless Persons. United Nations High Commissioner for Refugees.

UNICEF. (2009). The State of the World's Children-Special Edition: Celebrating 20 Years on the Convention on the Rights of the Child: New York, United States of America.

UNICEF. (2013). Global initiative on out-of-school children. Montreal, Quebec, Canada. 